\title{
SISTEM REKOMENDASI PEMILIHAN SMARTPHONE SNAPDRAGON 636 MENGGUNAKAN METODE SIMPLE MULTI ATTRIBUTE RATING TECHNIQUE (SMART)
}

\author{
Nur Shodik ${ }^{1}$, Neneng ${ }^{2}$, Imam Ahmad $^{3}$ \\ ${ }^{1}$ Program Studi Informatika \\ ${ }^{2}$ Program Studi Sistem Informasi Akuntansi \\ ${ }^{3}$ Program Studi Sistem Informasi \\ Fakultas Teknik dan IImu Komputer, Universitas Teknokrat Indonesia \\ e-mail: nurshodik9@gmail.com ${ }^{1}$,neneng@teknokrat.ac.id ${ }^{2}$ \\ imamahmad@teknokrat.ac.id ${ }^{3}$
}

\begin{abstract}
Abstrak
Pertumbuhan Smartphone secara drastis seringkali menyulitkan pengguna untuk memilih manakah pilihan yang tepat karena Smartphone memiliki spesifikasi yang beragam, untuk menyelesaikan masalah tersebut maka perlu dirancang sebuah sistem rekomendasi. Sistem rekomendasi merupakan model aplikasi dari hasil obsevarsi terhadap keadaan pengguna dan memelurkan model rekomendasi yang tepat agar sesuai keinginan pengguna.Sistem pemilihan smartphone diimplementasikan metode Simple Multi Attribute Rating Technique (SMART) untuk memberikan rekomendasi terhadap Smartphone yang menggunakan Snapdragon 636. Pengembangan sistem menggunakan Extreme Programming dengan empat tahapan meliputi planning, design, coding dan testing, pengujian Black Box Testing sebagai uji fungsionaltias web. Hasil penelitian menunjukkan bahwa pemilihan smartphone snapdragon 636 terbaik adalah Asus Zenfone Max Pro M1 dengan nilai 83.50 yang memiliki spesifikasi 4GB RAM, 64GB ROM, kapasitas 5000 mAh battery, sistem android Oreo (8.1), memiliki dual kamera 12MP+5MP dengan kamera depan 8MP, 18:09 resolusi layar dengan dukungan Hybrid Sim Card, Finger Print maupun Face Recognation dengan harga $\mathrm{Rp} 2.900 .000$
\end{abstract}

Kata kunci: Sistem Rekomendasi, Snapdragon 636, SMART, Extreme Programming, Black Box Testing

\begin{abstract}
The growth of Smartphones has quickly made it difficult for users to choose which one is the right one because Smartphones has various specifications to solve the problem has been designed a recommendation system. The recommendation system is an application model from the results of obsevsivity on the user's situation, therefore the recommendation system extends the right recommendation model to be recommended according to the user's desires. This system implements Simple Multi Attribute Rating Technique (SMART) method to provide recommendations for Smartphones Snapdragon 636 based. System development is carried out with four stages of Extreme Programming including planning, design, coding and testing, Black Box testing to state that the process flow, input output and a series of web system functional tests. The results of the analysis of the selection of the best alternative smartphone is the Asus Zenfone Max Pro M1 with a value of 83.50 which has a specification of $4 G B$ RAM, 64GB ROM, capacity of $5000 \mathrm{mAh}$ battery, Android Oreo system (8.1), has a dual 12MP + 5MP camera with 8MP front camera, 18: 09 screen resolution with support for Hybrid Sim Card, Finger Print and Face Recognation at a price of Rp. 2,900,000
\end{abstract}

Keywords: Recommendation System, Snapdragon 636, SMART, Extreme Programming, Black Box Testing 


\section{PENDAHULUAN}

Teknologi komunikasi tidak lepas dari perkembangan zaman yang begitu cepat, saat ini teknologi informasi berbasis mobile yang populer yaitu Telepon Pintar (Smartphone) dan berakibat sulitnya menentukan pilihan karena beragamnya spsifikasi Smartphone. Seperti laporan yang dirilis (Emarketer, 2014) [1] menyatakan bahwa akan terdapat dua miliar pengguna Smartphones aktif diseluruh dunia pada tahun 2016 dan Indonesia merupakan salah satu negara yang memiliki pertumbuhan terbesar di bawah China dan India, menurut laporan ini Indonesia akan melampaui 100 juta pengguna Smartphones aktif pada tahun 2018.

Secara lebih khusus tujuan dari penelitian ini dapat disusun berdasarkan tahapan yang akan dilakukan seperti membangun sebuah sistem berbasis web yang dapat membantu pengguna memilih Smartphone dan mengimplementasikan metode SMART (Simple Multi Attribute Rating Technique ) dalam perhitungan untuk menentukan alternatif terbaik pemilihan Smartphone. Penelitian dengan menerapkan metode SMART pernah dilakukan oleh Suryanto pada tahun 2015 dengan judul Sistem Pendukung Keputusan Pemilihan Karyawan Teladan dengan Metode SMART dan hasil penelitian ini adalah sebuah sistem yang mampu menghasilkan keputusan yang lebih objektif, terkomputerisasi dan mengurangi terjadinya humam error [2]. Rasmita pada tahun 2017 dengan judul Implementasi metode SMART ( Simple Multi Attribute Rating Technique ) dalam Pemilihan Hotel di Kota Palu dan hasil penelitian ini adalah sebuah sistem penunjang keputusan menggunakan SMART yang dapat digunakan untuk membantu calon pengunjung dalam menentukan hotel prioritas yang sesuai dengan kriteria yang diinginkan [3].

Sanjaya pada tahun 2015 dengan judul Rekomendasi Pembelian Grosir Pada Toko Mainan Menggunakan Metode SMART ( Simple Multi Attribute Rating Technique ) Dengan Google Maps dan hasil penelitian ini adalah diperolehnya rekomendasi yang menjadi faktor penentu untuk memudahkan pedagang atau pembeli mencari pembelian grosir mainan [4]. Hatta pada tahun 2017 dengan judul Pemilihan Pemain Terbaik Futsal Dengan Metode Simple Multi Attribute Rating Technique, Studi Kasus: Turnamen Futsal Di Samarinda dan hasil penelitian ini adalah sebuah sistem yang dapat membantu panitia dalam memilih pemain terbaik dalam jumlah yang banyak dan perhitungan yang akurat, serta akan memberikan rekomendasi kepada panitia untuk mengetahui pemain yang tepat untuk menjadi pemain terbaik [5]. Syahputra pada tahun 2017 dengan judul Sistem Pengambilan Keputusan Dalam Menentukan Kualitas Pemasukkan Pangan Segar Metode SMART dan hasil penelitiannya adalah sistem untuk mendukung pembuat dalam memilih antara beberapa alternatif, hasil terhadap penentuan kualitas pemasukkan pangan segar asal tumbuhan [6].

Berdasarkan permasalahan di atas maka perlu dirancang sebuah sistem web yang mampu menganalisa serta merekomendasikan Smartphone yang sesuai dengan kebutuhan pembeli. Agar sistem rekomendasi ini dapat berjalan dengan baik maka dibutuhkan informasi tentang spesifikasi untuk mendapatkan rekomendasi Smartphone yang diinginkan pembeli. Kriteria pengambilan Smartphone yang akan digunakan dalam penelitian ini adalah RAM (GB), ROM (GB), Battery (mAh), OS, Rear Camera, Front Camera, Harga, Resolution Screen, Sim Slot Card dan Security.

\section{TINJAUAN PUSTAKA}

\section{A. Sistem Pendukung Keputusan}

Menurut Pratiwi (2016) [7] sistem pendukung keputusan merupakan sistem berbasis komputer yang interaktif dalam membantu para pengambil keputusan dengan memanfaatkan data dan model untuk penyelesaian masalah yang tidak terstuktur dan salah satu bentuk sistem pendukung keputusan adalah adanya sistem rekomendasi. Sistem rekomendasi merupakan model aplikasi dari hasil 
rekomendasi yang tepat agar yang direkomendasikan sesuai keinginan pembeli, serta mempermudah pembeli mengambil keputusan yang tepat dalam menentukan produk yang akan digunakannya, observasi terhadap keadaan dan keinginan pembeli [8]. Pada kasusnya sistem rekomendasi dapat diterapkan adalah untuk menguji kelayakan usaha [9] dan jura rekomendasi rute pada game petualangan [10]

\section{B. Metode SMART}

SMART menggunakan linear additive model untuk meramal nilai setiap alternatif. SMART merupakan metode pengambilan keputusan yang fleksibel. SMART lebih banyak digunakan karena kesederhanaanya dalam merespon kebutuhan pembuat keputusan dan caranya menganalisa respon. Analisa yang terlibat adalah transparan sehingga metode ini memberikan pemahaman masalah yang tinggi dan dapat diterima oleh pembuat keputusan. Pembobotan pada SMART menggunakan skala antara 0 sampai 1 sehingga mempermudah perhitungan dan perbandingan nilai pada masing-masing alternatif. [11] Model fungsi utiliti linear yang digunakan oleh SMART adalah seperti berikut:

Maximize $\sum_{j=1}^{k} w_{j} \cdot u_{i j}, i=1, \ldots, n$

Dengan:

- $\quad w_{j}$ adalah nilai pembobotan kriteria ke-j dari k kriteria

- $u_{i j}$ adalah nilai utility alternatif i pada kriteria j

- Pemilihan keputusan mengidentifikasi mana dari $n$ alternatif yang mempunyai nilai fungsi terbesar.

- Nilai fungsi ini juga dapat digunakan untuk meranking $\mathrm{n}$ alternatif

Menghitung normalisasi bobot:

$n w_{j}=\frac{w_{j}}{\sum_{n=1}^{k} w_{n}}$.

Dengan:

- $n w_{j}$ adalah normalisasi bobot kriteria $k e-j$

- $\quad w_{j}$ adalah nilai kriteria ke-j
- K adalah jumlah kriteria

- $\quad w_{n}$ adalah bobot kriteria ke $\mathrm{n}$

Menghitung nilai utiliti

$u_{i j}=f\left(v_{i j}\right)$.

Dengan:

- $\quad u_{i j}$ adalah nilai utiliti kriteria ke-j untuk alternatif $\mathrm{i}$

- $v_{i j}$ adalah nilai kriteria ke-j untuk alternatif $\mathrm{i}$

- $\quad f\left(v_{i j}\right)$ adalah fungsi kriteria ke-j untuk alternatif $\mathrm{i}$

\section{Smartphone}

Menurut (Williams \& Sawyer, 2011)

[12] Smartphone merupakan telepon seluler dengan mikroprosesor, memori, layar dan modem bawaan. Smartphone merupakan ponsel multimedia yang menggabungkan fungsionalitas komputer dan handset sehingga menghasilkan gadget mewah dimana terdapat pesan teks, kamera pemutar musik dan video, game, akses email, tv digital, search enginee, pengolah informasi pribadi, fitur Global Position System (GPS), jasa telepon internet bahkan juga berfungsi sebagai kartu kredit.

Menurut (Fling, 2009) [13] terdapat beberapa sistem operasi pada smartphone yang umum digunakan salah satunya adalah Android dan berdasarkan (Statista, 2018) [14] kini Android hampir menguasai Market Share Smartphone yang ada dapat dilihat pada Gambar 1.

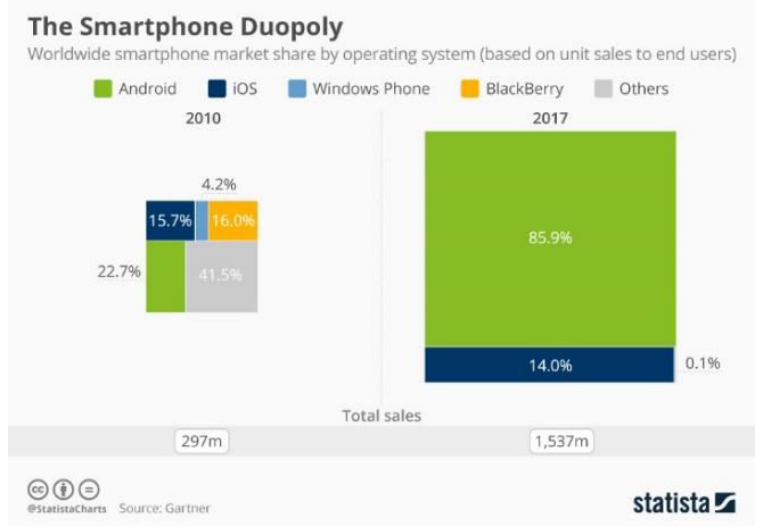

Gambar 1. Market Share Android 


\section{Snapdragon 636}

Snapdragon 636 merupakan salah satu System on Chip (SoC) yang dapat ditemui dismartphone menurut (Badawy \& Julien, 2003) [15] SoC adalah sebuah integrated circuit (IC) yang di dalamnya telah mengintegrasikan seluruh komponen komputer atau sistem elektronik lain. Di dalamnya terdapat fungsi-fungsi frekuensi radio dan analog. SoC ini sangat umum digunakan dalam pasar mobile computing karena memiliki konsumsi daya yang rendah. Penerapan yang umum adalah pada sistem embedded (embedded system).

Snapdragon 636 merupakan inovasi terbaru dari segi segmen Chipset kelas menengah. Berangkat dari Line Up Snapdragon 600, Platform Snapdragon 636 akan memberikan peningkatan yang signifikan sebesar $40 \%$ dalam kinerja, Gaming dan teknologi Display. Kunci utama dari Snapdragon 636 adalah perkenalan Cores CPU terbaru dari Qualcomm, Kryo 260. Kryo 260 yang disematkan dalam Snapdragon 636 diklaim akan mampu mencapai 1.8GHz (Qualcomm, 2017) [16].

\section{E. Unified Modeling Language (UML)} Menurut (Rosa \& Shalahuddin, 2013) [17] UML adalah bahasa yang telah menjadi standar untuk visualisasi, menetapkan, membangun dan mendokumentasikan sistem perangkat lunak dalam pemograman berorientasi objek. Sebuah permodelan bahasa adalah suatu bahasa dimana kata-kata dan aturannya berfokus pada penggambaran sistem secara konseptual dan fisik.

Hasil dari permodelan tadi adalah pengertian dari suatu sistem. Satu model saja tidak cukup untuk menggambarkan sistem secara keseluruhan, maka dibutuhkan banyak model yang berhubungan satu dengan yang lainnya untuk memberikan pengertian pada dasar dari sistem berikut merupakan keuntungan UML:

1. Sebagai bahasa pemodelan yang general-purpose, difokuskan pada pokok himpunan konsep yang dapat dipakai bersama dan menggunakan pengetahuan bersama dengan mekanisme perluasan.

2. Sebagai bahasa pemodelan yang mudah diaplikasikan, dapat diaplikasikan untuk bermacam tipe sistem (software dan non-software), domain dan metode atau proses.

3. Sebagai bahasa pemodelan standar industri, bukan merupakan bahasa yang tertutup atau satu-satunya, tapi bersifat terbuka dan sepenuhnya dapat diperluas.

\section{F. Extreme Programming (XP)}

Model XP didefinisikan sebagai suatu metode ringan yang menekankan pada komunikasi yang intens, hingga model pengerjaan yang interaktif dan incremental. Di dalam pengembangan sistem yang menggunakan XP terdapat empat tahapan, yaitu: Planning, Design, Coding, dan Testing dapat dilihat pada gambar Gambar 2 (Pressman, 2010) [18] .

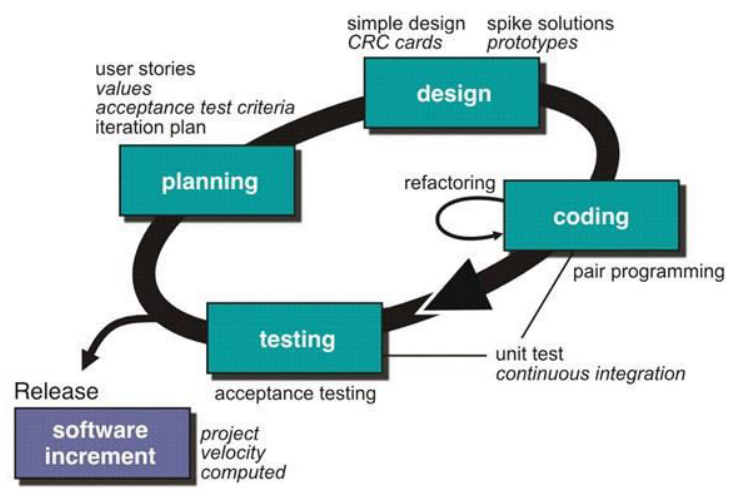

Gambar 2. Extreme Programming

\section{G. Black Box}

Menurut (Rosa 2014) [19] black box testing adalah menguji perangkat lunak dari segi spesifikasi fungsional tanpa menguji desain dan kode program. Pengujian dimaksudkan untuk mengetahui apakah fungsi-fungsi, masukan, dan keluaran dari perangkat lunak sesuai dengan spesifikasi yang dibutuhkan. Pengujian kotak hitam dilakukan dengan membuat kasus uji yang bersifat mencoba semua fungsi dengan memakai perangkat lunak apakah sesuai dengan spesifikasi yang dibutuhkan. Kasus uji yang dibuat untuk melakukan pengujian black box testing harus dibuat dengan 
kasus benar dan kasus salah. Black Box Testing dapat menemukan kesalahan kategori berikut

1. Jika ada fungsi yang tidak benar atau hilang

2. Kesalahan pada tampilan

3. Kesalahan dalam struktur data atau akses database external

4. Validitas fungsional

5. Batasan dari suatu data

\section{METODE PENELITIAN}

A. Kerangka Pemikiran

Kerangka penelitian merupakan bentuk dari keseluruhan proses dalam penelitian. Adapun kerangka penelitian dapat dilihat pada Gambar 3

\section{Masalah}

Bagaimana merancang sistem informasi pemilihan Smartphone Snapdragon 636 berbasis web?

Bagaimana mengimplementasikan metode SMART untuk pemilihan Smartphone?

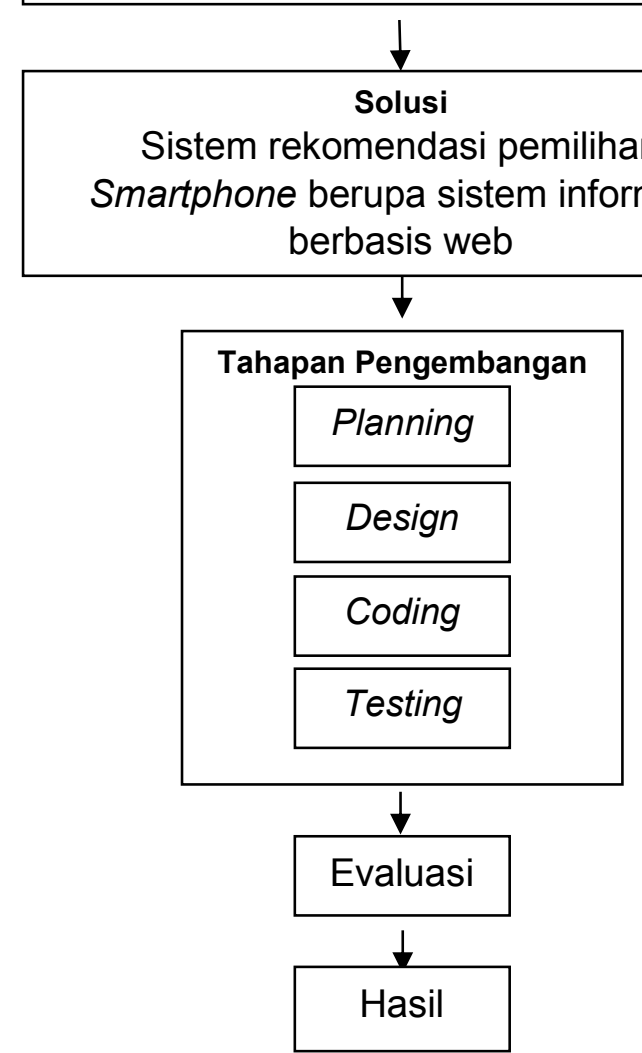

Gambar 3. Kerangka Pemikiran
B. Perhitungan SMART

Dalam penerapan metode SMART ada beberapa hal yang perlu dilakukan sebelum melakukan perhitungan nilai yaitu:

1. Identifikasi Alternatif

Dalam proses identifikasi alternatif dilakukan pengumpulan data smartphone dan didapatkan sebanyak 22 alternatif dapat dilihat pada Tabel 1

Tabel 1. Alternatif Smartphone

\begin{tabular}{|c|c|c|}
\hline & Smartphone & Versi \\
\hline A1 & Xiaomi Mi Max 3 & $4 \mathrm{~GB}, 64 \mathrm{~GB}$ \\
\hline A2 & Xiaomi Mi Max 3 & $\begin{array}{l}6 G B, \\
128 G B\end{array}$ \\
\hline A3 & Xiaomi Note $5 \mathrm{Al}$ & $3 G B, 32 G B$ \\
\hline A4 & Xiaomi Note $5 \mathrm{Al}$ & 4GB, 64GB \\
\hline A5 & Xiaomi Note $5 \mathrm{Al}$ & $6 \mathrm{~GB}, 64 \mathrm{~GB}$ \\
\hline A6 & $\begin{array}{l}\text { Xiaomi Note } 5 \\
\text { PRO }\end{array}$ & $3 \mathrm{~GB}, 32 \mathrm{~GB}$ \\
\hline A7 & $\begin{array}{l}\text { Xiaomi Note } 5 \\
\text { PRO }\end{array}$ & $4 \mathrm{~GB}, 64 \mathrm{~GB}$ \\
\hline A8 & $\begin{array}{l}\text { Xiaomi Note } 5 \\
\text { PRO }\end{array}$ & $6 \mathrm{~GB}, 64 \mathrm{~GB}$ \\
\hline A9 & Asus Zenfone 5 & 4GB, 64GB \\
\hline A10 & $\begin{array}{l}\text { Asus Zenfone } \\
\text { Max Pro }\end{array}$ & $3 G B, 32 G B$ \\
\hline A11 & $\begin{array}{l}\text { Asus Zenfone } \\
\text { Max Pro }\end{array}$ & $4 \mathrm{~GB}, 64 \mathrm{~GB}$ \\
\hline A12 & $\begin{array}{l}\text { Asus Zenfone } \\
\text { Max Pro }\end{array}$ & $6 \mathrm{~GB}, 64 \mathrm{~GB}$ \\
\hline A13 & Nokia X6 & 4GB, 32GB \\
\hline A14 & Nokia X6 & 4GB, 64GB \\
\hline A15 & Nokia X6 & 6GB, 64GB \\
\hline A16 & Meizu E3 & $6 \mathrm{~GB}, 64 \mathrm{~GB}$ \\
\hline A17 & Meizu E3 & $\begin{array}{l}\text { 6GB, } \\
128 \mathrm{~GB}\end{array}$ \\
\hline A18 & Lenovo Z5 & $6 \mathrm{~GB}, 64 \mathrm{~GB}$ \\
\hline A19 & Lenovo Z5 & $\begin{array}{l}\text { 6GB, } \\
128 \mathrm{~B}\end{array}$ \\
\hline A20 & Vivo Z1i & $\begin{array}{l}4 \mathrm{~GB}, \\
128 \mathrm{~GB}\end{array}$ \\
\hline A21 & BQ Aquarius X2 & $3 \mathrm{~GB}, 32 \mathrm{~GB}$ \\
\hline A22 & BQ Aquarius X2 & 4GB, 64GB \\
\hline
\end{tabular}


2. Pemberian bobot kriteria

Bobot yang diperoleh akan dinormalisasikan dimana bobot setiap kriteria yang diperoleh akan dibagikan dengan hasil jumlah setiap bobot kriteria. Seperti pada tabel 2

Tabel 2. Bobot kriteria

\begin{tabular}{|c|l|c|c|}
\hline Kriteria & Keterangan & $\begin{array}{c}\text { Bobot } \\
(\mathrm{Wj})\end{array}$ & $\sum W j$ \\
\hline C1 & RAM & 12 & 0.12 \\
\hline C2 & ROM & 10 & 0.1 \\
\hline C3 & Battery Life & 13 & 0.13 \\
\hline C4 & $\begin{array}{l}\text { Operating } \\
\text { System (OS) }\end{array}$ & 10 & 0.1 \\
\hline C5 & $\begin{array}{l}\text { Rear Camera } \\
\text { (Main) }\end{array}$ & 6 & 0.06 \\
\hline C5 & $\begin{array}{l}\text { Rear Camera } \\
\text { (Depth) }\end{array}$ & 4 & 0.04 \\
\hline C6 & Front Camera & 8 & 0.08 \\
\hline C7 & Harga & 12 & 0.12 \\
\hline C8 & $\begin{array}{l}\text { Resolution } \\
\text { Screen }\end{array}$ & 8 & 0.08 \\
\hline C9 & Sim Slot Card & 8 & 0.08 \\
\hline C10 & Security & 9 & 0.09 \\
\hline & & 100 & 1 \\
\hline & & & \\
\hline
\end{tabular}

3. Memberikan nilai kriteria dengan parameter yang ada. Nilai tersebut dapat dilihat pada Tabel 3

Tabel 3. Konfigurasi Nilai Kriteria

\begin{tabular}{|c|c|c|}
\hline Kriteria & Parameter & $\begin{array}{c}\text { Nilai } \\
\text { Kriteria }\end{array}$ \\
\hline \multirow{4}{*}{ RAM } & $3 G B$ & 1 \\
\cline { 2 - 3 } & $4 G B$ & 2 \\
\cline { 2 - 3 } & $6 \mathrm{~GB}$ & 3 \\
\hline \multirow{4}{*}{ ROM } & $32 \mathrm{~GB}-64 \mathrm{~GB}$ & 1 \\
\cline { 2 - 3 } & $64 \mathrm{~GB}-96 \mathrm{~GB}$ & 2 \\
\cline { 2 - 3 } & $96 \mathrm{~GB}-128 \mathrm{~GB}$ & 3 \\
\hline \multirow{5}{*}{ Battery Life } & $\begin{array}{c}3060(\mathrm{mAh})- \\
3873(\mathrm{mAh})\end{array}$ & 1 \\
\cline { 2 - 3 } & $\begin{array}{c}3873(\mathrm{mAh})- \\
4687(\mathrm{mAh})\end{array}$ & 2 \\
\cline { 2 - 3 } & $\begin{array}{c}4687(\mathrm{mAh})- \\
5500(\mathrm{mAh})\end{array}$ & 3 \\
\hline
\end{tabular}

\begin{tabular}{|c|c|c|}
\hline \multirow{3}{*}{$\begin{array}{l}\text { Operating } \\
\text { System } \\
\text { (OS) }\end{array}$} & 7.1 .2 & 1 \\
\hline & 8.0 & 2 \\
\hline & 8.1 & 3 \\
\hline \multirow{3}{*}{$\begin{array}{l}\text { Rear } \\
\text { Camera } \\
\text { (Main) }\end{array}$} & $12 \mathrm{MP}$ & 1 \\
\hline & $13 \mathrm{MP}$ & 2 \\
\hline & 16MP & 3 \\
\hline \multirow{3}{*}{$\begin{array}{l}\text { Rear } \\
\text { Camera } \\
\text { (Depth) }\end{array}$} & $2 \mathrm{MP}-8 \mathrm{MP}$ & 1 \\
\hline & $8 \mathrm{MP}-14 \mathrm{MP}$ & 2 \\
\hline & 14MP - 20MP & 3 \\
\hline \multirow{3}{*}{$\begin{array}{l}\text { Front } \\
\text { Camera }\end{array}$} & $8 \mathrm{MP}-12 \mathrm{MP}$ & 1 \\
\hline & $12 \mathrm{MP}-16 \mathrm{MP}$ & 2 \\
\hline & $16 \mathrm{MP}-20 \mathrm{MP}$ & 3 \\
\hline \multirow{3}{*}{ Harga } & $\begin{array}{c}\text { Rp4,333,333 - } \\
\text { Rp5,500,000 }\end{array}$ & 1 \\
\hline & $\begin{array}{c}\text { Rp3,166,667 - } \\
\text { Rp4,333,333 }\end{array}$ & 2 \\
\hline & $\begin{array}{c}\text { Rp2,000,000 - } \\
\text { Rp3,166,667 }\end{array}$ & 3 \\
\hline \multirow{3}{*}{$\begin{array}{l}\text { Resolution } \\
\text { Screen }\end{array}$} & $17: 09$ & 1 \\
\hline & 18:09 & 2 \\
\hline & 19:09 & 3 \\
\hline \multirow{3}{*}{$\begin{array}{l}\text { Sim Slot } \\
\text { Card }\end{array}$} & Dual Sim & 1 \\
\hline & Hybrid & 2 \\
\hline & Dedicated & 3 \\
\hline \multirow{3}{*}{ Security } & None & 1 \\
\hline & Finger Print & 2 \\
\hline & $\begin{array}{c}\text { Finger Print + } \\
\text { Face Unlock }\end{array}$ & 3 \\
\hline
\end{tabular}

Nilai-nilai kriteria tersebut kemudia dikonversikan menjadi sebuah nilai kriteria data baku untuk menentukan nilai utility dapat dilihat pada tabel 4

Tabel 4. Konfigurasi Nilai Utility

\begin{tabular}{|c|c|}
\hline Nilai Kriteria & Nilai \\
\hline 3 & 100 \\
\hline 2 & 75 \\
\hline 1 & 50 \\
\hline
\end{tabular}

4. Menghitung masing-masing nilai alternatif dengan penilaian/utilitas terhadap setiap alternatif. 
HASIL PENELITIAN DAN PEMBAHASAN

A. Implementasi Interface

Dalam tahapan implementasi sistem memberikan gambaran desain yang telah di rancang pada tahap pengembangan sistem rekomendasi pemilihan smartphone

\section{a. Halaman Utama SmartOne}

Halaman utama SmartOne halaman pertama yang muncul saat setelah sukses melakukan login, dalam halaman utama terdapat menu yang dapat diakses menuju perhitungan SMART. Hasil implementasi dapat dilihat pada Gambar 4

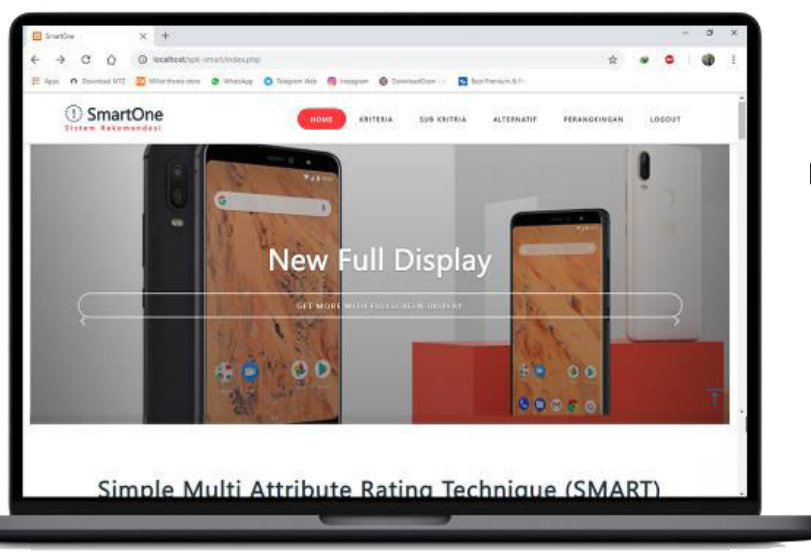

Gambar 4 Halaman Utama

\section{b. Halaman Tambah Kriteria}

Halaman tambah kriteria merupakan halaman yang digunakan untuk input kriteria beserta bobot kriteria, pada penelitian ini jumlah bobot maksimal adalah 100. Hasil implementasi dapat dilihat pada Gambar 5

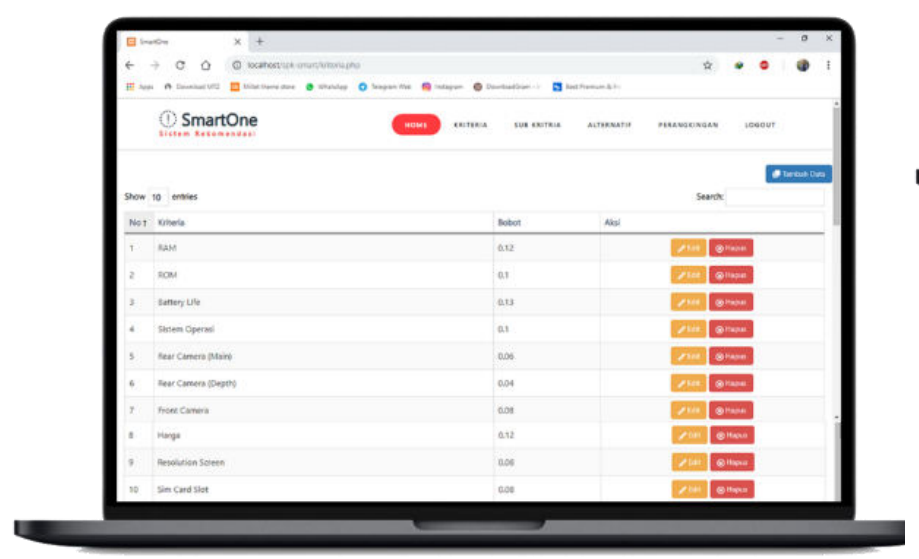

Gambar 5 Halaman Tambah Kriteria
Halaman tambah sub kriteria merupakan halaman untuk memberikan nilai parameter untuk masing-masing kriteria. Hasil implementasi dapat dilihat pada Gambar 6

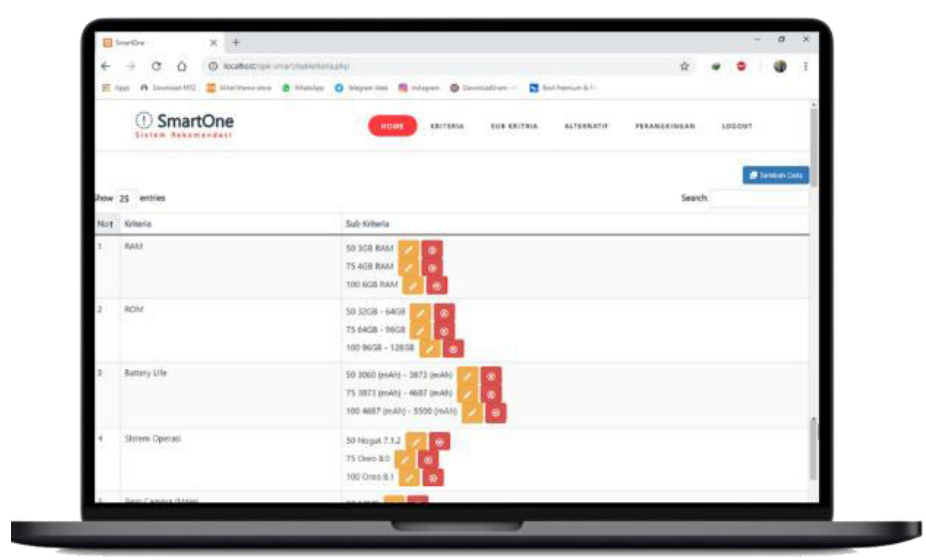

Gambar 6 Halaman Tambah Sub Kriteria

d. Halaman Alternatif

Halaman alternatif adalah halaman untuk input altrernatif smartphone, dalam penilitian ini data smartphone yang ada sebanyak 22 smartphone. Hasil implementasi dapat dilihat pada Gambar 8

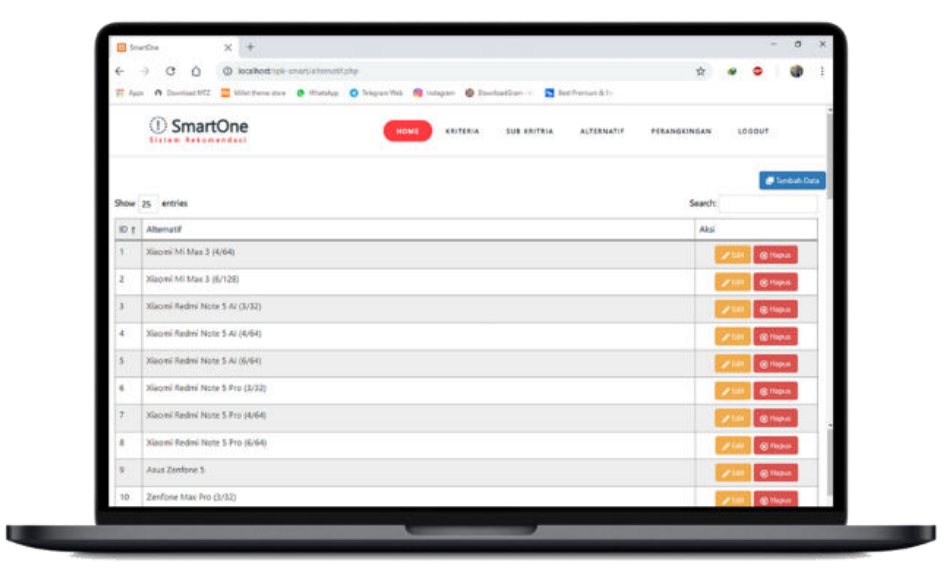

Gambar 8 Alternatif

e. Halaman Perankingan

Halaman perangkingan adalah halaman untuk memberikan nilai pada setiap alternatif yang ada . Hasil implementasi dapat dilihat pada Gambar 9

c. Halaman Tambah Sub Kriteria 


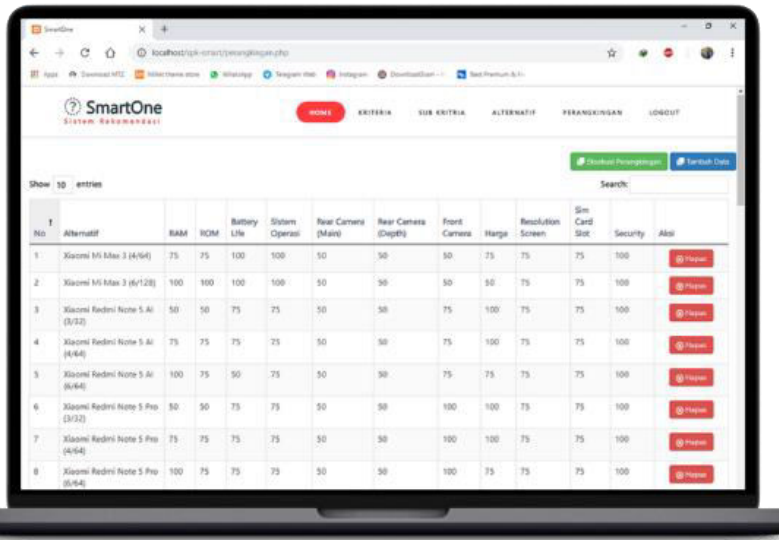

Gambar 9 Perankingan

f. Halaman Hasil Prankingan

Halaman hasil perangkingan adalah halaman yang menampilkan hasil perhitungan dengan metode SMART yang dapat membantu menyelesaikan rekomendasi smartphone. Hasil implementasi hasil perangkingan dapat dilihat pada Gambar 10

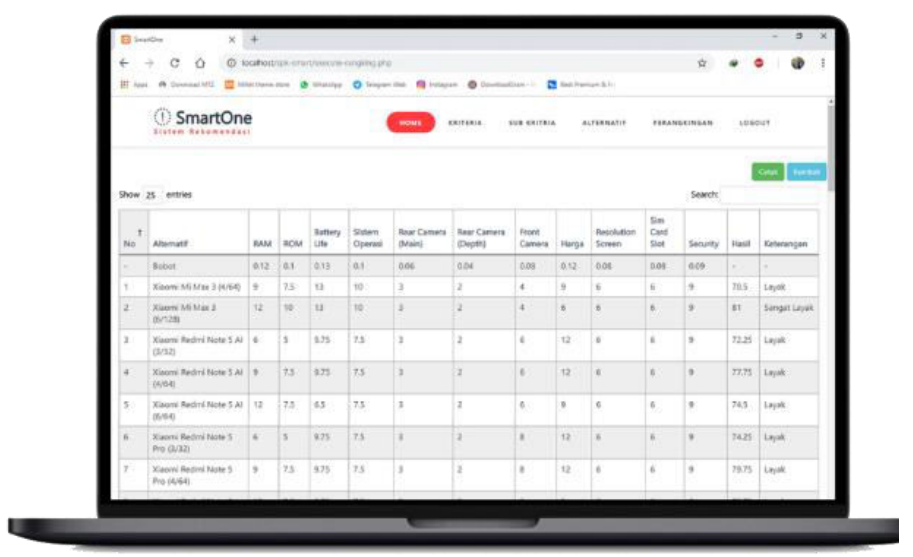

Gambar 10 Hasil Perankingan

\section{g. Halaman About Us}

Halaman About Us berisi tentang profil singkat penulis, pembimbing dan penguji. Hasil implementasi dapat dilihat pada Gambar 11

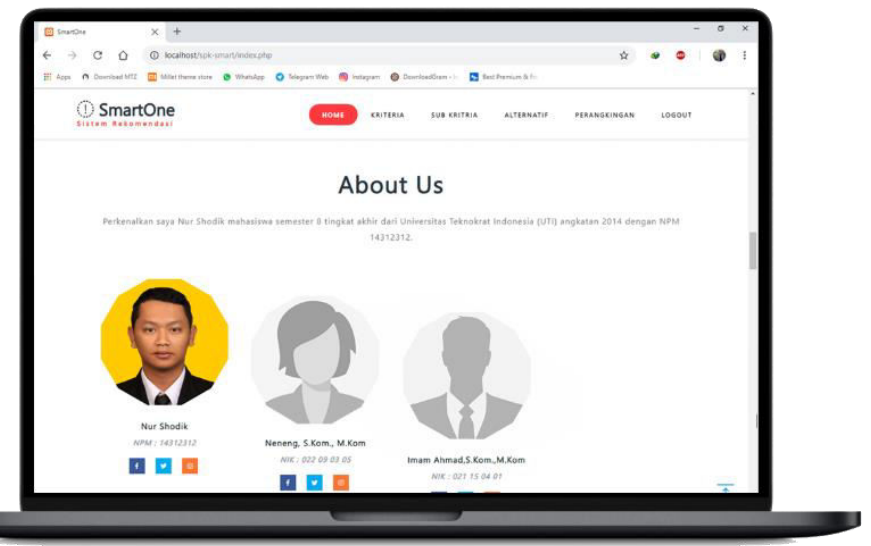

Gambar 11 Halaman About Us

B. Hasil Pengujian

SmartOne diuji dalam tahap uji fungsionalitas sistem (Black Box Testing). Hasil dari pengujian SmartOne sebagai website sistem rekomendasi pemilihan smartphone menggunakan Snapdragon 636 adalah perbandingan antara perhitungan excel dan perhitungan pada website. Hasil perbandingan dapat dilihat pada tabel 5 dan Gambar 4.10

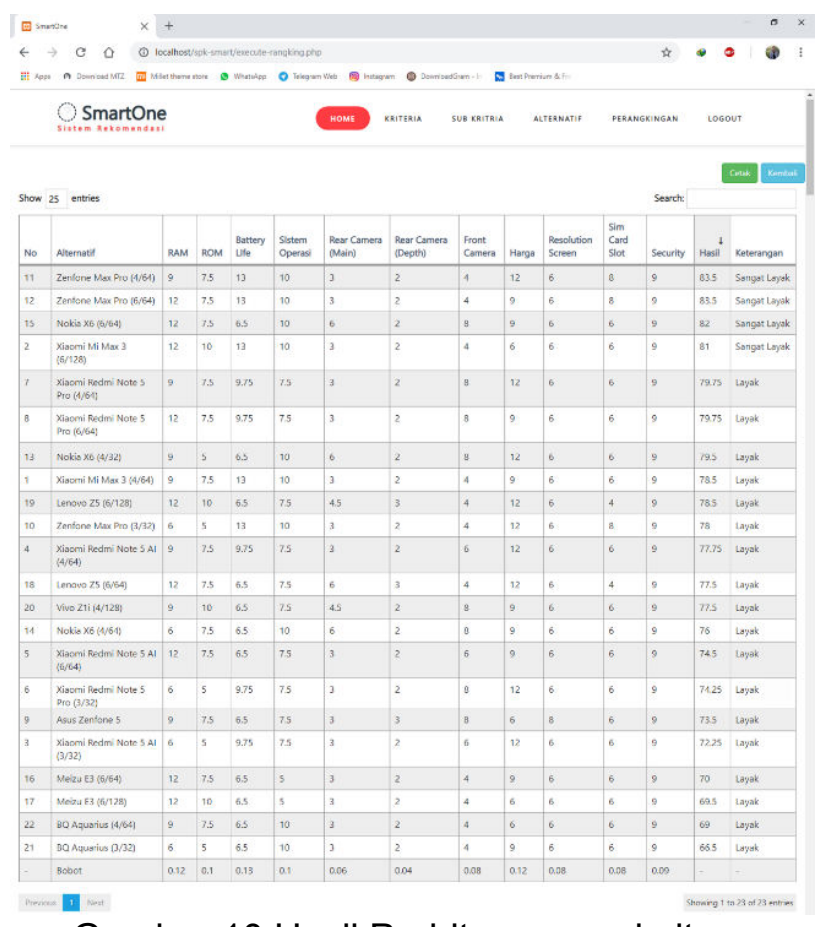

Gambar 10 Hasil Perhitungan website 
Tabel 5 hasil perhitungan

\begin{tabular}{|c|c|c|c|}
\hline & Alterntif & Versi & Hasil \\
\hline A11 & $\begin{array}{l}\text { Asus Zenfone } \\
\text { Max Pro M1 }\end{array}$ & $4 \mathrm{~GB}, 64 \mathrm{~GB}$ & 83.50 \\
\hline A12 & $\begin{array}{l}\text { Asus Zenfone } \\
\text { Max Pro M1 }\end{array}$ & $6 \mathrm{~GB}, 64 \mathrm{~GB}$ & 83.50 \\
\hline A15 & Nokia X6 & $6 \mathrm{~GB}, 64 \mathrm{~GB}$ & 82.00 \\
\hline A2 & $\begin{array}{l}\text { Xiaomi Mi } \\
\text { Max } 3\end{array}$ & $\begin{array}{c}\text { 6GB, } \\
128 \mathrm{~GB}\end{array}$ & 81.00 \\
\hline A7 & $\begin{array}{l}\text { Xiaomi Note } 5 \\
\text { PRO }\end{array}$ & $4 \mathrm{~GB}, 64 \mathrm{~GB}$ & 79.75 \\
\hline A8 & $\begin{array}{l}\text { Xiaomi Note } 5 \\
\text { PRO }\end{array}$ & $6 \mathrm{~GB}, 64 \mathrm{~GB}$ & 79.75 \\
\hline A13 & Nokia X6 & 4GB, 32GB & 79.50 \\
\hline A1 & $\begin{array}{l}\text { Xiaomi Mi } \\
\text { Max } 3\end{array}$ & $4 \mathrm{~GB}, 64 \mathrm{~GB}$ & 78.50 \\
\hline A19 & Lenovo Z5 & $\begin{array}{c}6 \mathrm{~GB}, \\
128 \mathrm{~GB}\end{array}$ & 78.50 \\
\hline A10 & $\begin{array}{l}\text { Asus Zenfone } \\
\text { Max Pro M1 }\end{array}$ & $3 \mathrm{~GB}, 32 \mathrm{~GB}$ & 78.00 \\
\hline A4 & $\begin{array}{l}\text { Xiaomi Note } 5 \\
\text { Al }\end{array}$ & $4 \mathrm{~GB}, 64 \mathrm{~GB}$ & 77.75 \\
\hline A18 & Lenovo Z5 & $6 \mathrm{~GB}, 64 \mathrm{~GB}$ & 77.50 \\
\hline A20 & Vivo Z1i & $\begin{array}{c}4 \mathrm{~GB}, \\
128 \mathrm{~GB}\end{array}$ & 77.50 \\
\hline A14 & Nokia X6 & $4 \mathrm{~GB}, 64 \mathrm{~GB}$ & 76.00 \\
\hline A5 & $\begin{array}{l}\text { Xiaomi Note } 5 \\
\mathrm{Al}\end{array}$ & $6 \mathrm{~GB}, 64 \mathrm{~GB}$ & 74.50 \\
\hline A6 & $\begin{array}{l}\text { Xiaomi Note } 5 \\
\text { PRO }\end{array}$ & $3 \mathrm{~GB}, 32 \mathrm{~GB}$ & 74.25 \\
\hline A9 & $\begin{array}{l}\text { Asus Zenfone } \\
5\end{array}$ & $4 \mathrm{~GB}, 64 \mathrm{~GB}$ & 73.50 \\
\hline A3 & $\begin{array}{l}\text { Xiaomi Note } 5 \\
\mathrm{Al}\end{array}$ & $3 \mathrm{~GB}, 32 \mathrm{~GB}$ & 72.25 \\
\hline A17 & Meizu E3 & $\begin{array}{c}6 \mathrm{~GB}, \\
128 \mathrm{~GB}\end{array}$ & 70.00 \\
\hline A16 & Meizu E3 & $6 \mathrm{~GB}, 64 \mathrm{~GB}$ & 69.50 \\
\hline A22 & $\begin{array}{l}\text { BQ Aquarius } \\
\text { X2 }\end{array}$ & $4 \mathrm{~GB}, 64 \mathrm{~GB}$ & 69.00 \\
\hline A21 & $\begin{array}{l}\text { BQ Aquarius } \\
\text { X2 }\end{array}$ & $3 G B, 32 G B$ & 66.50 \\
\hline
\end{tabular}

Dilihat dari tabel 5 dan gambar 4.10 menunjukan bahwa alternatif smartphone terbaik adalah Asus Zenfone Max Pro M1 dengan nilai 83.50 yang memiliki spesifikasi 4GB RAM, 64GB ROM, kapasitas 5000 mAh battery, sistem android Oreo (8.1), memiliki dual kamera $12 \mathrm{MP}+5 \mathrm{MP}$ dengan kamera depan 8MP, 18:09 resolusi layar dengan dukungan Hybrid Sim Card, Finger Print maupun Face Recognation dengan harga Rp 2.900.000

\section{KESIMPULAN DAN SARAN}

A. Kesimpulan

Berdasarkan hasil penelitian dan pembahasan sistem rekomendasi pemilihan smartphone menggunakan snapdragon 636 dengan metode Simple Multi Attribute Rating Technique (SMART), maka dapat disimpulkan:

1. Telah dibangun sebuah sistem berbasis web dengan nama SmartOne yang dapat membantu pengguna memilih Smartphone berdasarkan keinginan, kebutuhan dan anggaran sehingga pengguna akan mendapatkan spesifikasi yang terbaik.

2. Hasil penelitian menunjukkan bahwa pemilihan smartphone snapdragon 636 terbaik adalah Asus Zenfone Max Pro M1 dengan nilai 83.50 yang memiliki spesifikasi 4GB RAM, 64GB ROM, kapasitas 5000 mAh battery, sistem android Oreo (8.1), memiliki dual kamera $12 \mathrm{MP}+5 \mathrm{MP}$ dengan kamera depan 8MP, 18:09 resolusi layar dengan dukungan Hybrid Sim Card, Finger Print maupun Face Recognation dengan harga Rp 2.900.000

\section{B. Saran}

Berdasarkan kesimpulan dari hasil penelitian yang telah diuraikan, maka saran yang dapat diberikan untuk penelitian selanjutnya terhadap Sistem Rekomendasi Pemilihan Smartphone Menggunakan Snapdragon 636 yaitu:

1. Pengembangan aplikasi dapat dibuat dalam bentuk aplikasi mobile android

2. Penelitian selanjutnya dapat digunakan metode seperti Collaborative Filtering Recommendation, Content-Based Recommendation atau Item-Based Collaborative Filtering dalam penyelesaian rekomendasi

3. Aplikasi dapat dikembangkan dengan mencakup batasan masalah yang lebih luas tidak hanya yang menggunakan snapdragon 636. 


\section{REFERENSI}

[1]. eMarketer. 2 Billion Consumers Worldwide to Get Smartphone by 2016. [Internet]. 2016 [cited 2018 May 28]. Available from: https://www.emarketer.com/m/Article/ 2-Billion-Consumers-Worldwide-toGet-Smartphone-by-2016/1011694

[2]. Suryanto, Safrizal M. Sistem Pendukung Keputusan Pemilihan Karyawan Teladan dengan Metode SMART. J CorelT. 2015;1 (2).

[3]. Rasmita H, Rudji R, Hendra S. Implementasi Metode SMART (Simple Multi Attribute Rating Technique ) dalam Pemilihan Hotel di Kota Palu. In: in Seminar Nasional Multi Disiplin IImu. 2017.

[4]. Sanjaya A, Marisa D, Maharani S. Rekomendasi Pembelian Grosir Pada Toko Mainan Menggunakan Metode SMART ( Simple Multi Attribute Rating Technique ) Dengan Google Maps. In: Seminar Sains dan Teknologi FMIPA Unmul. Samarinda; 2015.

[5]. Syahputra T, Yetri M, Armaya SD. Sistem Pengambilan Keputusan Dalam Menentukan Kualitas Pemasukkan Pangan Segar Metode SMART. J Teknol dan Sist Inf. 2017;1 (1):7-12.

[6]. Hatta HR, Gunawan B, Khairina DM. Pemilihan Pemain Terbaik Futsal Dengan Metode Simple Multi Attribute Rating Technique, Studi Kasus: Turnamen Futsal Di Samarinda. J Inform. 2017; 11(1).

[7]. Pratiwi H. Buku Ajar Sistem Pendukung Keputusan. Yogyakarta: Deepublish; 2016.

[8]. Mcginty L, Smyth B. Adaptive Selection: Analysis Of Critiquing And Preference. Int $\mathrm{J}$ Electron Commer. 2006;11 (2):35-57.

[9]. Ahmad I, Hermadi I, Arkeman Y. Financial feasibility study of waste cooking oil utilization for biodiesel production using ANFIS. Indones $\mathrm{J}$ Electr Eng Comput Sci. 2015;546-54.

[10]. Widodo W, Ahmad I. Penerapan Algoritma A Star $\left(A^{*}\right)$ pada Game
Petualangan Labirin Berbasis Android, Khazanah Informatika. J IImu Komput dan Inform. 2018;57-63.

[11]. Taylor J j., Love B. Simple Multi Attribue Rating Technique for Renewable Energy Development (SMART REDD). Def Model Simul Appl Methodol Technol. 2014;11(3):227-323.

[12]. Williams BK, Sawyer SC. Using Information Technology: A Practical Introduction to Computer \& Communication. 9th ed. NewYork: McGraw-Hill; 2011.

[13]. Fling B. Mobile Design and Development. 1st ed. United State Of America: O'Reilly Media, Inc.; 2009.

[14]. Statista. The Smartphone Doupoly [Internet]. 2018 [cited 2018 May 25]. Available from: https://www.statista.com/chart/3268/s martphone-os-market-share

[15]. Badawy W, Julien G. System-On-Chip For Real TIme Application. Canada: Springer Science-Business Medis, LLC.; 2003.

[16]. Qualcomm. Qualcomm Snapdragon 636 mobile platform [Internet]. 2017 [cited 2018 May 18]. Available from: https://www.qualcomm.com/news/rele ase/2017/01/17/QualcommSnapdragon-636-mobile-platformDelivers-Significant-Increases

[17]. Rosa AS, Shalahuddin M. Rekayasa Perangkat Lunak Tersrtruktur dan Berorientasi Objek. Bandung: Informatika; 2014.

[18]. Pressman RS. Software Engineering: apractioner approach. 7th ed. NewYork: McGraw-Hill; 2010.

[19]. Rosa AS. Analisis dan Desain Sistem Informasi. Bandung: Informatika; 2009. 